Review

\title{
Availability of Global and National Scale Land Cover Products and Their Accuracy in Mountainous Areas of Ethiopia: A Review
}

\author{
Binyam Tesfaw Hailu ${ }^{12 *}$, Mekbib Fekadu ${ }^{13}$, Thomas Naus ${ }^{1}$ \\ ${ }^{1}$ Philipps-Universität Marburg, Department of Geography, Deutschhausstraße 12, 35032 Marburg, Germany \\ ${ }^{2}$ Addis Ababa University, School of Earth Sciences, P.O.Box: 1176, Addis Ababa, Ethiopia. \\ Binyam.tesfaw@aau.edu.et \\ ${ }^{3}$ Addis Ababa University, Department of Plant Biology, P.O.Box: 1176, Addis Ababa, Ethiopia. \\ Mekbib.fkadu@yahoo.com \\ * Correspondence: binyam.hailu@geo.uni-marburg.de; Tel.: +49-160-774-9543
}

\begin{abstract}
A large variety of remote sensing-based land use/land cover (LULC) products are currently available on national and global scales. This literature review and in-situ validation study evaluates the suitability of these products for local scale applications in the complex terrain of the Ethiopian mountains. For the review, 146 research papers were analyzed. Most studies (73\%) have been published since 2013 and are based on individually computed maps. Not a single study relied on readily available LULC products. Nine readily available LULC products with 20, 30, 300, 500 and $1,000 \mathrm{~m}$ spatial resolution have been identified at national and global scales. To complement and extend this body of research, the recent (since 2013) LULC products were validated using 185 ground truth points collected in the Bale Mountains National Park between 1,500 and 4,385 $\mathrm{m}$ a.s.l. The results indicate a rather poor overall accuracy $(<50 \%)$.
\end{abstract}

Keywords: LULC Products, systematic review, Bale Mountains National Park, Ethiopia

\section{Introduction}

Land use/land cover (LULC) information is heavily utilized for mapping environmental conditions and monitoring changes such as deforestation, land degradation, drought or urbanization [1,2]. LULC change is a major driver of biodiversity loss and affects climate change response, ecosystem structure and functioning, water and energy balance, and agroecological potential [3]. Adequate information on LULC is therefore required on global, national, and local scales.

In Ethiopia, deforestation is one of the major processes of LULC change. Fuel wood collection, timber extraction, commercial agriculture and charcoal production are the primary direct drivers. Indirect drivers are population growth, essential for commodities, governance and economic growth [4-7]. LULC change is also a major challenge with a strong impact on the agricultural development process and the implementation of the country's main development strategies, such as the Growth and Transformation Plan (GTP) developed by Ministry of Finance and Economic Development (MoFED) and the 2011 Climate Resilient Green Economy strategy (CRGE) [8].

Remote sensing provides complete, area-wide observations of LULC at a variety of temporal and spatial scales. Many studies describe the potential of satellite sensors and analysis techniques to retrieve environmental variables and monitor biological and physical processes relevant to global change research. For example, researchers use such data for forest resources studies [9], vegetation mapping [10], forest health studies in terms of cost effectiveness and resolution [11], land degradation assessment [12], crop production forecast [13], urban planning and management [14], climate change studies [15], road extraction [16] and meteorology applications [17].

Although researchers, organizations and individuals produce LULC maps at global to regional scales for many applications, the accuracy of these products in high-altitude areas and their 
utilization for local scale applications is still unknown. Therefore, this research aims to identify the available LULC products, review literatures regarding usage of LULC products in Ethiopia and evaluate accuracy of these products at a local scale (high-altitude range area) using systematic review and meta-analysis methods, respectively.

\section{Study area, source of data and methods}

The study area is in the Bale Mountains National Park (BMNP) within the Eastern Afromontane Biodiversity Hotspot (EABH) [19]. The area stretches from $39.47^{\circ}$ to $39.95^{\circ} \mathrm{E}$ and $6.49^{\circ}$ to $7.15^{\circ} \mathrm{N}$ and spans an elevation range between 1,500 and 4,385 $\mathrm{m}$ a.s.l. (Figure 2).

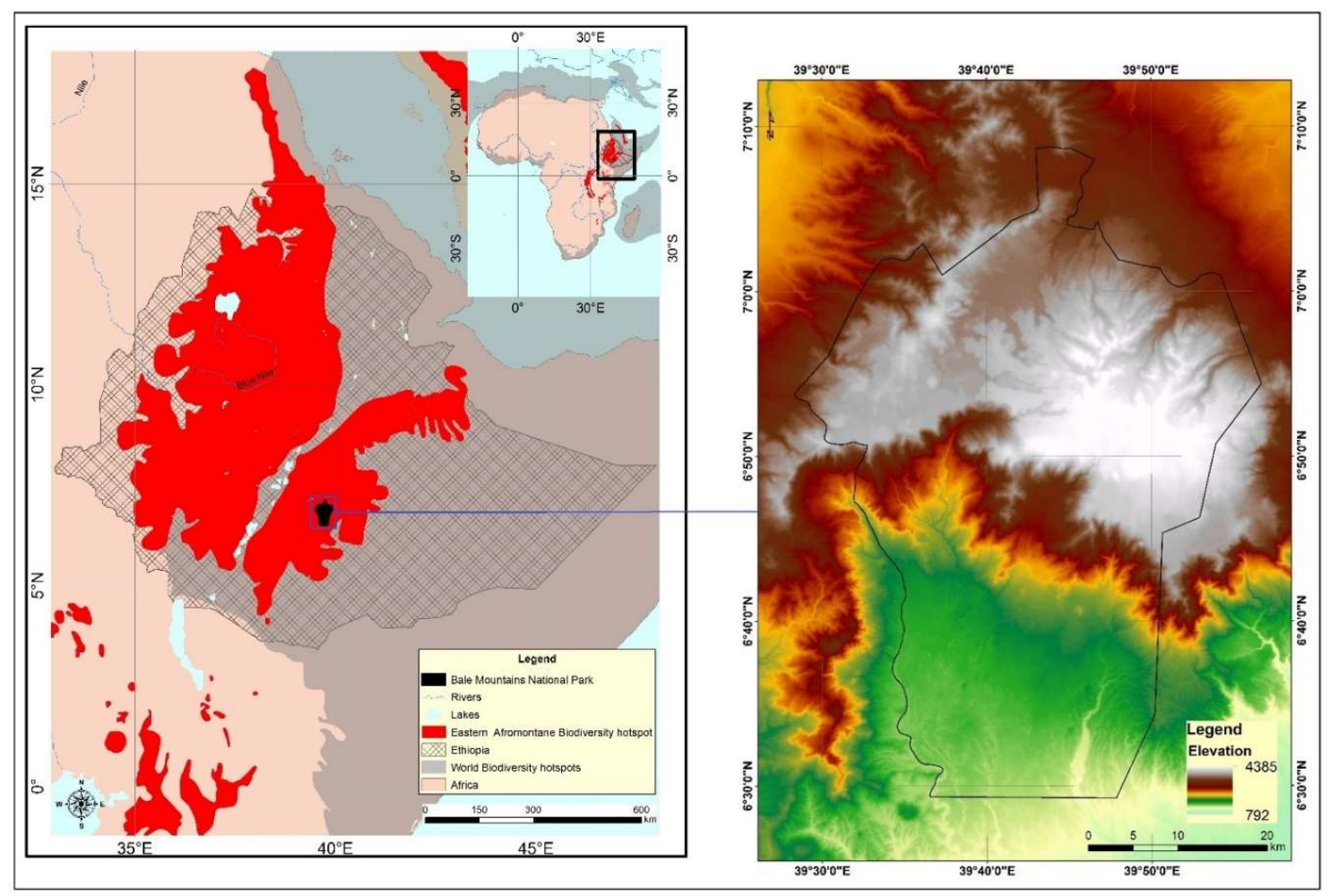

Figure 1. Bale Mountains National Park within the Eastern Afromontane Biodiversity hotspot and its elevation profile from the Shuttle Radar Topographic Mission (SRTM) 30m digital elevation model.

\subsection{Literature review}

For the literature review, we systematically collected 146 studies focusing on LULC mapping and its use in Ethiopia. The studies were all published in peer-reviewed journals between 2000 and 2018. We followed the systematic review approach by Cook et al. [18] and used descriptive statistics to synthesize the results. First, we clearly formulate the question: "Do researchers utilize existing LULC products in Ethiopia?". Second, we defined inclusion and exclusion criteria for retrieving literature from the Google Scholar search engine. The set was based on i) the year of publication and ii) the geographic location, i.e. '2000 < "publication year" < 2018 AND geographic location = "Ethiopia"'. This returned 146 studies. Third, the literature was synthesized based on study location, elevation range, use of satellite images and LULC products, publication year and accuracy assessment results. Finally, quantitative data synthesis was applied to elucidate whether the literature used readily available national to global scale LULC products. 


\subsection{National to global scale LULC products used within the reviewed literature}

Many LULC products were used in the 146 reviewed studies. Of these, only nine were readily available on a national to global scale. These are the Moderate Resolution Imaging Spectroradiometer (MODIS) Land Cover, the Global Land Cover 2000, 2005 and 2009 (GlobCover V2.2 and 2.3), the Ethiopian Land Cover Maps by the Regional Center for Mapping of Resources for Development (RCMRD) and the Ethiopian Mapping Agency (EMA) the GlobeLand30, the Global Land Cover by the National Mapping Organization (GLCNMO), the UN FAO Global Land Cover Network (GLCSHARE), the Africa Land Cover Maps (ALCM) by Midekisa et al. [1], and the Sentinel2 Global Land Cover (S2GLC).

The MODIS Land Cover product has five types (Type 1 to 5) of classification schemes that retrieve land cover properties based on one year of observations by Terra and Aqua MODIS. In this paper, the International Geosphere Biosphere Programme (IGBP) Global Vegetation Classification Scheme (GVCS) with 17 land cover classes was used (MODIS Land Cover Product Version 051 [19]).

The Global Land Cover 2000 product is produced from $1 \mathrm{~km}$ Satellite Pour l'Observation de la Terre (SPOT 4) observations acquired between November 1999 and December 2000 [20, 21]. The product uses the United Nation Land Cover Classification System (UN-LCCS) after unsupervised classification (ISODATA) [22] and contains two levels of land cover information: a detailed level with 44 land cover classes for each continent [23] and a harmonized level with 22 regional classes [20].

The global Land Cover 2005 product (GlobCover V2.2) was derived by regionally-tuned and automatically classified MEdium-spectral Resolution Imaging Spectrometer (MERIS, Envisat satellite system) observations between December 2004 and June 2006 [24]. Again, the UN-LCCS is used as the classification system. For the Global Land Cover 2009 (GlobCover V2.3), MERIS observations between January 2009 and December 2009 were used [25, 26].

The RCMRD and EMA LULC products are produced from 39 Landsat TM and ETM images from 2003, 2008 and 2013 as part of the "Land Cover Mapping for the Development of Green House Gas Inventories in East and Southern Africa" project by RCMRD and NASA SERVIR-Eastern and Southern Africa. The observations were acquired from the USGS website and preprocessed by RCMRD-SERVIR Africa [27]. In the case of Ethiopia, the project was coordinated through the government-appointed national greenhouse gases (GHG) team led by the EMA.

The GlobeLand30 LULC product provided by China maps global land cover at 30m spatial resolution [28, 29]. It uses a Pixel-Object-Knowledge based (POK-based) operational approach with two steps in the determination of land feature classes. First, the classification of 10 land cover classes is decomposed into simpler per-class classifications in a prioritized sequence and second, the perclass classification results are merged together. A knowledge-based interactive verification step is integrated to improve the quality of data product.

The Global Land Cover by the National Mapping Organizations (GLCNMO) is a $1 \mathrm{~km}$ global land cover product based on 16-day MODIS observation composites from 2003 [30, 31]. It also uses the aforementioned UN-LCCS classification system. Supervised and independent classification methods were used to derive 14 and six (urban, open tree, mangrove, wetland, snow/ice, and water) classes, respectively. The Global Land Cover Share (GLC-SHARE) product is a beta release from 2014 by the UN Food and Agriculture Organization (FAO) [32]. The project's objective is to derive the best available global land cover map from different global, regional, and national scale databases such as GlobCover 2009 and MODIS Vegetation Continuous Fields (VCF).

The African Land Use Land Cover Map (ALULCM) product by Midekisa et al. [1] provides annual (2000 to 2015) land cover information produced on the continental scale for Africa. It uses dayand night-time lights satellite observations from Landsat 7 (Enhanced Thematic Mapper) ETM+ [33] and Operational Linescan System (OLS) flown on Defense Meteorological Satellite Program (DMSP) satellites [34]. The Sentinel-2 Global Land Cover (S2GLC) product uses Copernicus Sentinel-2 Earth observation imagery to provide a fine spatial resolution with global coverage $[35,36]$. It is produced by the ESA project S2GLC through the scientific Exploitation of Operational Missions (SEOM) using a supervised pixel-based approach. 
2 of 16

\subsection{Ground truth data for Bale Mountains National Park}

To evaluate the aforementioned national to global scale LULC products, ground truth data was collected throughout the BMNP in 2016. The data is grouped into the major LULC classes that are present in the study region (trees, shrubland, herbaceous grassland, cropland, and barren land, see Table 1). Google Earth imagery from 2013 was cross-referenced to ensure that the ground truth sites have not changed since 2013 and can be compared with the following LULC products: MODIS IGBP2013, RCMRD and EMA-2013, GLCNMO-2013, GLC-SHARE-2014, ALCM-2015, and S2GLC-2016. The respective LULC product classes were reclassified to the classes of the ground truth information according to Table 2.

Table 1. User-defined LULC class descriptions based on UN-LCCS, IGBP-GVCS.

\begin{tabular}{|c|c|c|}
\hline $\begin{array}{c}\text { User-Defined } \\
\text { Classes }\end{array}$ & Description (UN-LCCS) & Description (IGBP-GVCS) \\
\hline Trees & $\begin{array}{c}\text { Tree cover, broadleaved, evergreen; }>15 \% \text { tree } \\
\text { cover; closed }>40 \% \text { tree cover; open } 15-40 \% \\
\text { tree cover; deciduous, needle-leaved, } \\
\text { evergreen; mixed leaf type }\end{array}$ & $\begin{array}{l}\text { Evergreen needleleaf, broadleaf } \\
\text { forest; deciduous needleleaf } \\
\text { forest; mixed forest }\end{array}$ \\
\hline $\begin{array}{c}\text { Grassland } \\
\text { (Herbaceous) }\end{array}$ & $\begin{array}{l}\text { Herbaceous cover, closed-open (i) natural, (ii) } \\
\text { pasture; sparse herbaceous; regularly flooded } \\
\text { herbaceous cover }\end{array}$ & Grasslands and wetlands \\
\hline Shrubland & $\begin{array}{c}\text { Shrub cover, closed-open, evergreen (sparse } \\
\text { tree layer); shrub cover, closed-open, } \\
\text { deciduous (sparse tree layer) }\end{array}$ & Closed and open shrublands \\
\hline Cropland & $\begin{array}{c}\text { Cultivated and managed areas (i) terrestrial; } \\
\text { (ii) aquatic (=flooded during cultivation), and } \\
\text { under terrestrial; (iii) tree crop \& shrubs } \\
\text { (perennial); (iv) herbaceous crops (annual), } \\
\text { non-irrigated; (v) herbaceous crops (annual), } \\
\text { irrigated }\end{array}$ & $\begin{array}{l}\text { Croplands; cropland/natural } \\
\text { vegetation mosaic }\end{array}$ \\
\hline Barren land & Bare areas & Barren or sparsely vegetated \\
\hline
\end{tabular}




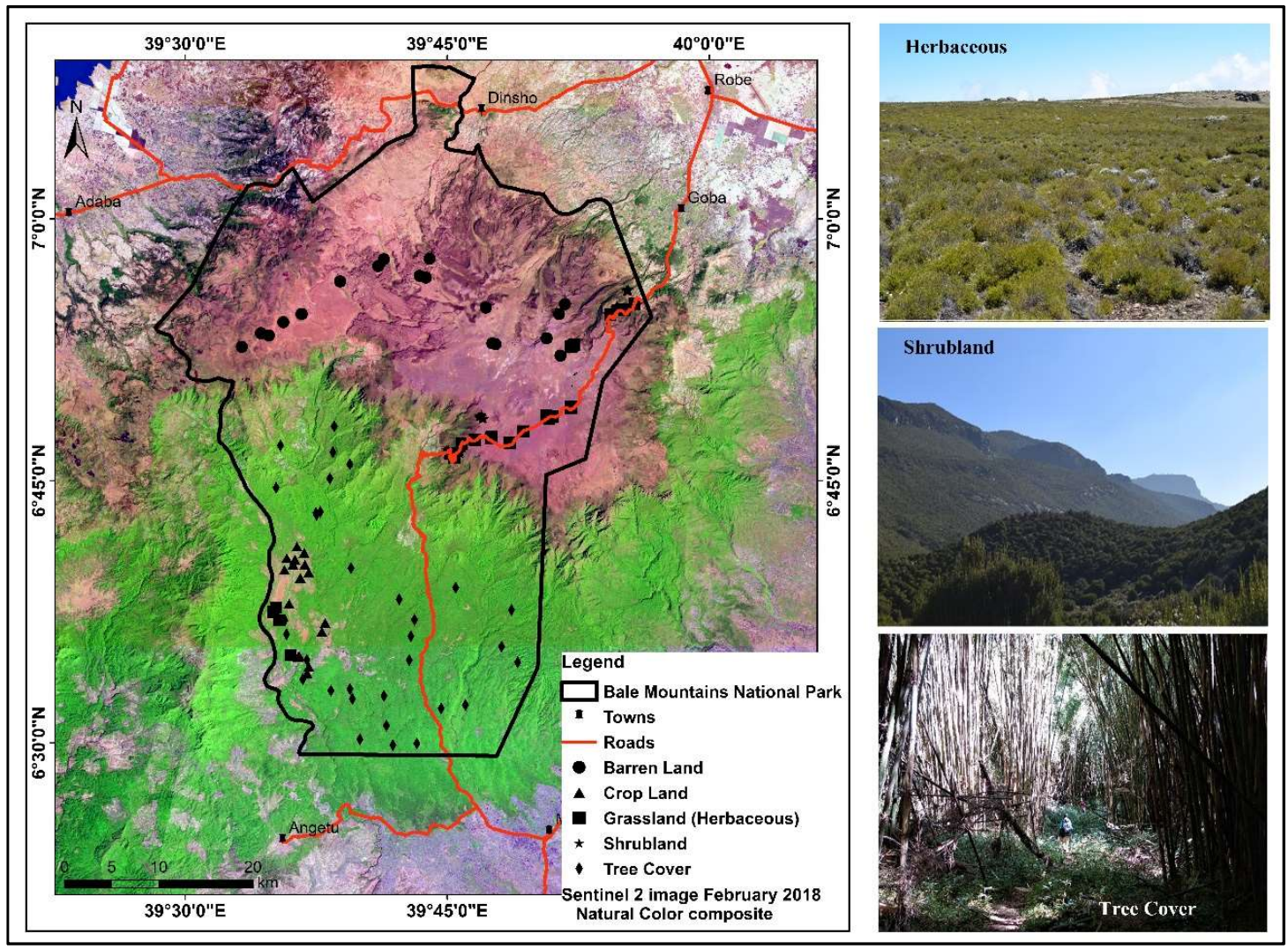

Figure 2. Map showing the distribution of ground truth points in BMNP.

Table 2. User-defined classes and associated classification code of LULC products.

\begin{tabular}{ccccccc}
\hline \multirow{2}{*}{$\begin{array}{c}\text { LULC } \\
\text { Products }\end{array}$} & Classification & \multicolumn{5}{c}{ User-Defined Land Use Land Cover Classes } \\
\cline { 3 - 7 } & System & Trees (1) & $\begin{array}{c}\text { Grassland } \\
\text { Herbaceous) } \\
\text { (2) }\end{array}$ & $\begin{array}{c}\text { Shrubland } \\
\text { (3) }\end{array}$ & $\begin{array}{c}\text { Cropland } \\
\text { (4) }\end{array}$ & $\begin{array}{c}\text { Barren } \\
\text { land (5) }\end{array}$ \\
\hline MODIS & IGBP-GVCS & $2,4,51$ & 10,11 & $6,7,9,8$ & 12,14 & 16 \\
GLC 2000 & UN-LCCS & $3,4,7$, & $13,14,15$ & 11 & 18 & 19 \\
GlobCover & & 10 & & & & \\
V2.2 \& 2.3 & UN-LCCS & 40,60, & 120,140 & $30,130,150$ & 14,20 & 200 \\
RCMRD \& & IPCC Scheme II & $2,7,11$, & $8,10,13$ & 16,18 & 3,4 & $5,9,17$ \\
EMA & Combined & 20 & 30,60 & 40 & 10 & 90 \\
GlobeLand30 & UN-LCCS & $1,2,3$ & 8,9 & 7 & 13 & 17 \\
GLCNMO & UN-LCCS & 4 & 3,6 & 5 & 2 & 9 \\
GLC-SHARE & - & 3,4 & - & 2 & - & $5,6,7$ \\
ALCM & Combined & 1 & 3,5 & 2 & 4 & - \\
S2GLC & & & & & & \\
\hline
\end{tabular}

1 Land cover class code based on the classification system used in each LULC product. The code descriptions are available as a supplementary file (Supplementary Document 1). 


\section{Results and Discussion}

\subsection{Available LULC products in Ethiopia (national to global scale)}

Table 3 shows the nine LULC products available from 2000 to 2018 at the global or national scale in terms of satellite image used, spatial resolution, geospatial data type, classification system, number of classes, overall accuracy, year and source. These LULC products have 20, 30, 300, 500 and $1000 \mathrm{~m}$ spatial resolutions. Overall, the classification accuracy of these products ranges from 67.5\% (GlobCover-2005) to 88\% (AFLC). Altogether the nine LULC products provide 40 time slices with the highest number of products (four) available for 2003, 2008 and 2013 (see Figure 3). Figure 4 and Figure 5 illustrate the S2GLC 2016 and GLC-SHARE 2014 with $20 \mathrm{~m}$ and $1 \mathrm{~km}$ spatial resolutions, respectively.

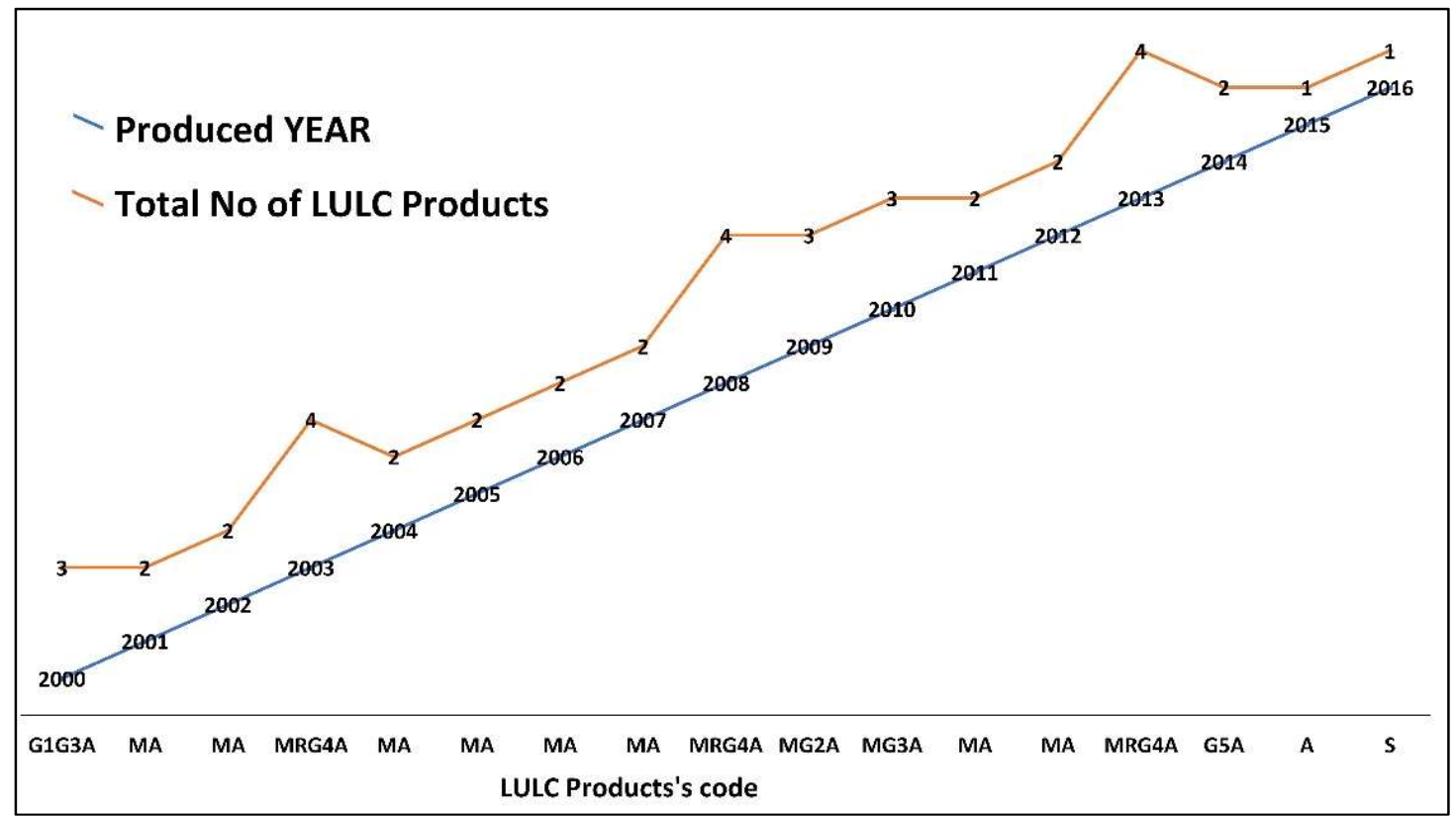

Figure 3. LULC products identified from national and global scale between 2000 and 2018 (product codes from Table 3). 
2 of 16

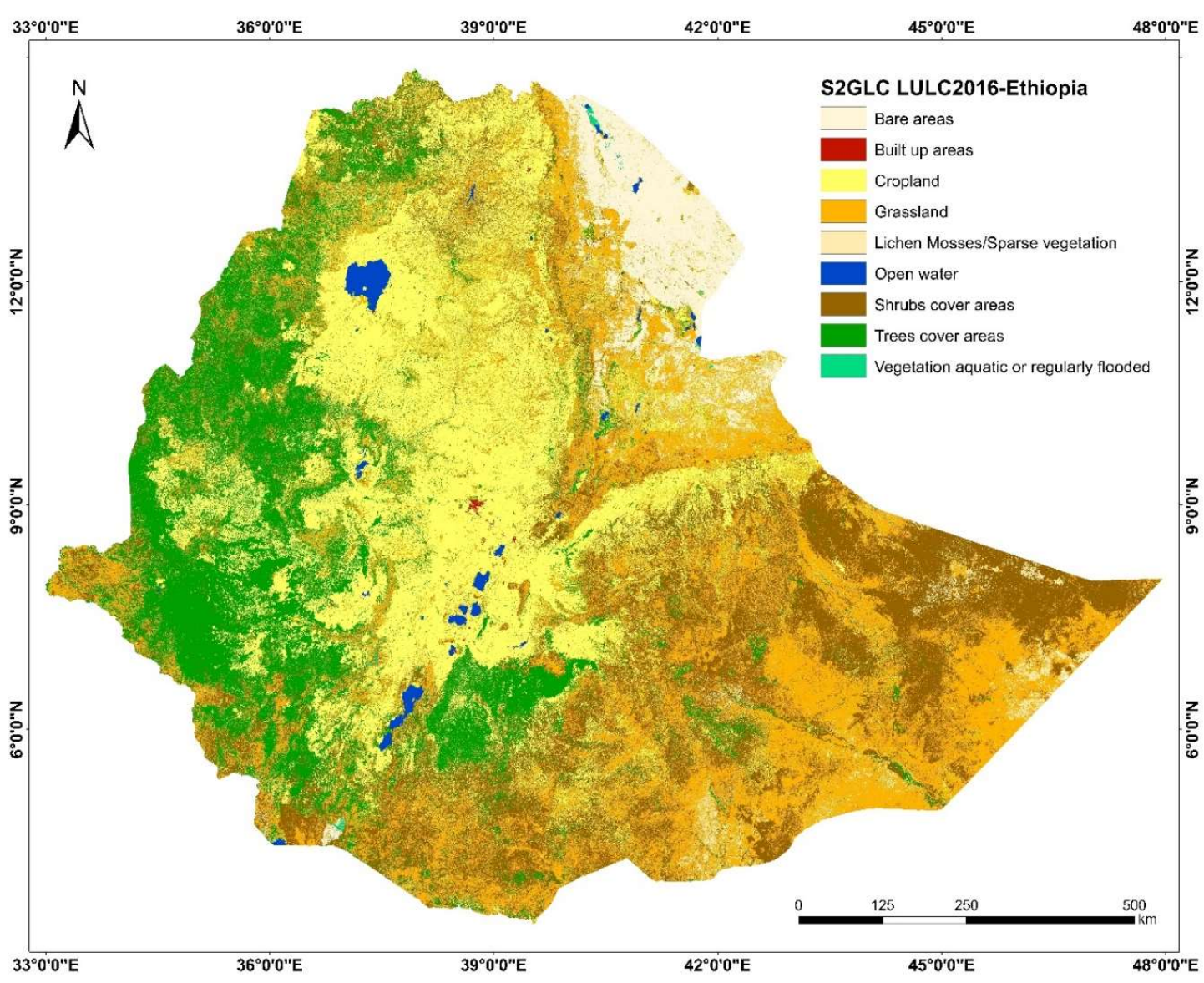

Figure 4. The S2GLC (2016) LULC product for Ethiopia with 20m spatial resolution. 
Table 3. Land Use Land Cover products for Ethiopia between the years 2000 and 2018

\begin{tabular}{|c|c|c|c|c|c|c|c|c|c|c|}
\hline Product name & Code & Satellite image & $\begin{array}{c}\text { Spatial res. of } \\
\text { satellite } \\
\text { image }\end{array}$ & $\begin{array}{c}\text { Product } \\
\text { spatial res. }\end{array}$ & $\begin{array}{c}\text { Geospatial } \\
\text { data type }\end{array}$ & Classification system & $\begin{array}{l}\text { No. of } \\
\text { classes }\end{array}$ & Overall accuracy & Year & Source \\
\hline MODIS & $\mathrm{M}$ & MODIS & $500 \mathrm{~m}$ & $500 \mathrm{~m}$ & HDF-EOS & $\begin{array}{l}\text { International Geosphere } \\
\text { Biosphere Programme - } \\
\text { global vegetation classification } \\
\text { scheme (IGBP-GVCS) }\end{array}$ & 17 & $75 \%$ & $\begin{array}{l}\text { 2001-2013 } \\
\text { (annually) }\end{array}$ & NASA \\
\hline GLC 2000 & G1 & $\begin{array}{l}\text { SPOT vegetation } \\
\text { sensor }\end{array}$ & $1 \mathrm{~km}$ & $1 \mathrm{~km}$ & grid & UN-LCCS & 22 & $68.60 \%$ & 2000 & FAO \\
\hline $\begin{array}{l}\text { GlobCover } \\
\text { V2.2 \& } 2.3\end{array}$ & G2 & MERIS & $300 \mathrm{~m}$ & $300 \mathrm{~m}$ & GeoTiff & UN-LCCS & 22 & $\begin{array}{c}67.5 \% \text { (V2.2) and } 73 \% \\
\text { (V2.3) }\end{array}$ & $\begin{array}{l}2005 \text { and } \\
2009\end{array}$ & ESA \\
\hline $\begin{array}{l}\text { RCMRD \& } \\
\text { EMA }\end{array}$ & $\mathrm{R}$ & Landsat & $30 \mathrm{~m}$ & $30 \mathrm{~m}$ & GeoTiff & $\begin{array}{l}\text { Intergovernmental Panel on } \\
\text { Climate Change (IPCC) } 6 \text { land } \\
\text { over categories for Scheme II }\end{array}$ & 16 & $\begin{array}{c}87.97 \% \text { (2003), } 86.68 \% \\
\text { (2008), No data for } \\
2013\end{array}$ & $\begin{array}{c}2003,2008 \\
\text { and } 2013\end{array}$ & $\begin{array}{l}\text { RCMRD and } \\
\text { EMA }\end{array}$ \\
\hline GlobeLand30 & G3 & $\begin{array}{c}\text { Landsat, MODIS, } \\
\text { HJ, FY-3 }\end{array}$ & $\begin{array}{c}30 \mathrm{~m} \\
1 \mathrm{~km}(2003)\end{array}$ & $\begin{array}{c}30 \mathrm{~m} \\
1 \mathrm{~km}(2003)\end{array}$ & GeoTiff & $\begin{array}{l}\text { the existing different land } \\
\text { cover classification systems }\end{array}$ & 10 & $80 \%$ & $\begin{array}{l}2000 \text { and } \\
2010\end{array}$ & [28] \\
\hline GLCNMO & G4 & $\begin{array}{l}\text { MODIS and } \\
\text { Landsat }\end{array}$ & $\begin{array}{c}\text { (2008 and } \\
2013)\end{array}$ & $\begin{array}{c}\text { (2008 and } \\
2013)\end{array}$ & GeoTiff & UN-LCCS & 20 & $76.50 \%$ & $\begin{array}{l}\text { 2003, } 2008 \\
\text { and } 2013\end{array}$ & {$[30,31]$} \\
\hline GLC-SHARE & G5 & $\begin{array}{l}\text { Aggregate of } \\
\text { LULC maps }\end{array}$ & & $1 \mathrm{~km}$ & $\begin{array}{l}\text { GeoTiff } \\
\text { Raster- }\end{array}$ & UN-LCCS & 11 & $80.20 \%$ & $\begin{array}{c}2014 \\
2000-2015\end{array}$ & \\
\hline ALCM & A & Landsat & $30 \mathrm{~m}$ & $500 \mathrm{~m}$ & GeoTiff & $\begin{array}{c}- \\
\text { existing legends used within }\end{array}$ & 7 & $88 \%$ & (annually) & [1] \\
\hline S2GLC & $\mathrm{s}$ & Sentinel 2 & $10 / 20 \mathrm{~m}$ & $20 \mathrm{~m}$ & GeoTiff & global land cover databases & 15 & $82.8 \%$ & 2016 & ESA \\
\hline
\end{tabular}




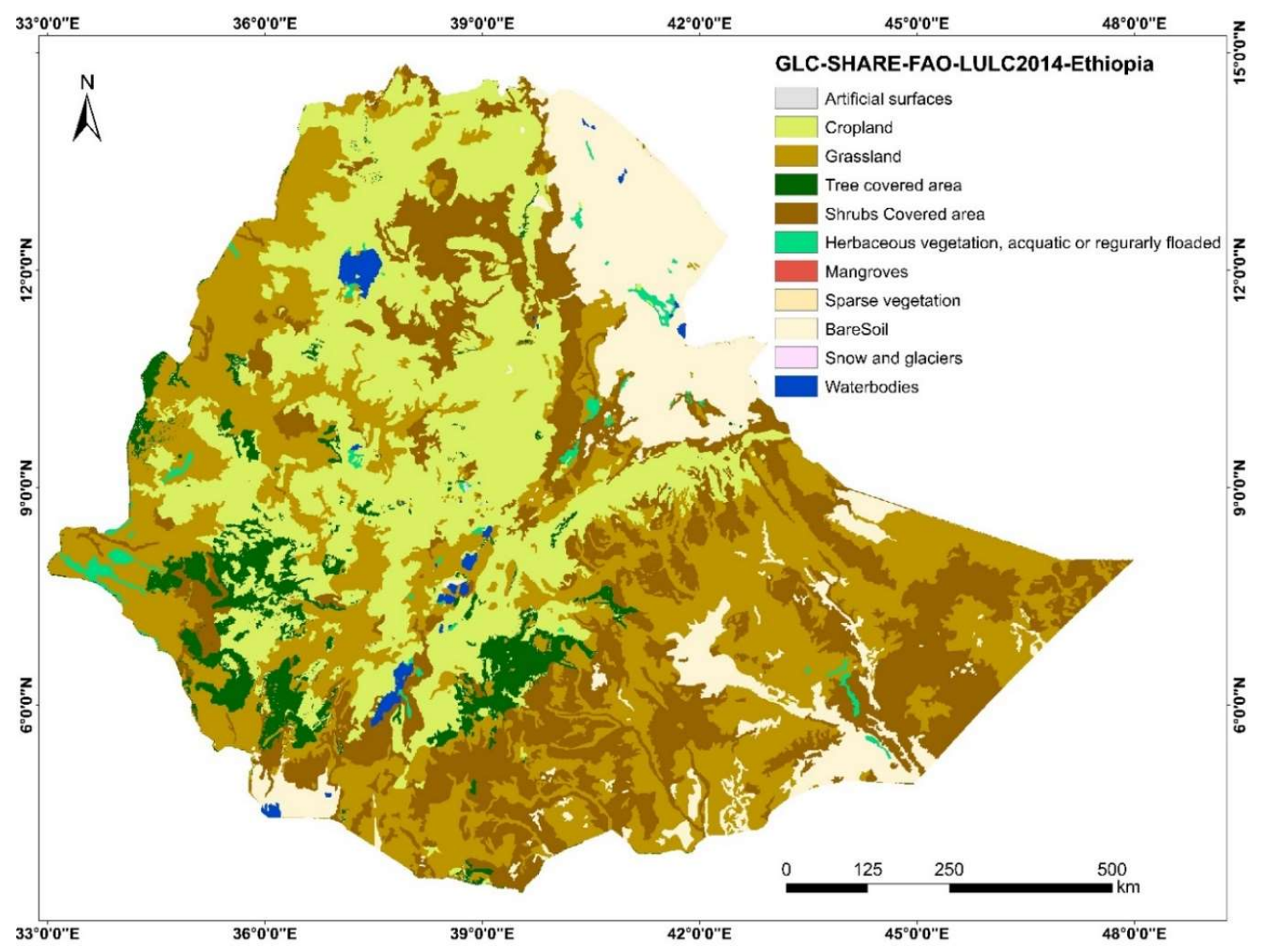

Figure 5. The GLC-SHARE (2014) LULC product of Ethiopia with $1 \mathrm{~km}$ spatial resolution.

\subsection{Systematic literature review}

The 146 publications were synthesized based on study area, elevation, use of satellite images, LULC products, publication year and accuracy assessment result (see supplementary document 2). In general, the number of publications per year increased until 2017 (see Figure 6C) reaching a maximum of 26 in 2017. This signifies the importance of LULC information for Ethiopia within the scientific community. LULC analyses were completed throughout Ethiopia with most of the studies (73) completed in the northern part of Ethiopia, in the Tigray and Amhara regions. The second most studied area (39 publications) is the central region, which includes the Ethiopian Rift Valley. In terms of elevation, 140 studies were conducted in an altitude range above 1,500 $\mathrm{m}$ a.s.l. and only six in areas below $1,500 \mathrm{~m}$ a.s.l.

In the publications, LULC was mapped using satellite images (Figure 6B). Landsat was the most popular satellite, used in 126 papers, while SPOT was used in 10 studies and 10 publications used other data sources, such as Advanced Spaceborne Thermal Emission and Reflection Radiometer (ASTER) (2), aerial photographs (2), and QuickBird (1). Three publications studied LULC change analysis using community participation by questionnaires and interviews without using satellite images, while two other publications used field observation LULC data. In terms of accuracy, more than $90 \%, 80-90 \%, 70-80 \%$, and $60-70 \%$ accuracy was reported in 10,32 , eight and one publication, respectively. In 95 research papers, the accuracy of the classifications was not mentioned. The results in Figure 6B show that most researchers prefer to create a new LULC map by analyzing freely available satellite images like Landsat instead of using one of the available LULC products introduced in 3.1.

Of the 146 publications, 36 were from peer reviewed journals with environmental themes such as Science of the Total Environment [37-40]; Agriculture, Ecosystems and Environment [41-43]; Environmental Monitoring and Assessment [7, 41, 44-46]; Environmental Systems Research [47-49]; 
International Journal of Environmental Studies [39,50, 51] and Journal of Environment and Earth Science [52-54].

The LULC maps are used in a variety of application areas. These include watershed management (40), hydrology (31), lowland management (21), highland management (20), urban studies (12), social studies (12), forest management (6) and agriculture (4). This implies that authors find the LULC analysis quite important for water-related applications such as watershed management or surface and groundwater hydrology in Ethiopian river basins like the Upper Blue Nile, Tekeze, Awash, Baro, Ghibe and Rift Valley Lakes basins. Most studies were done in Upper Blue Nile River basin [37,40,43, 45,47, 55-62], followed by studies in the Central and Rift Valley Lakes basin [63-67].
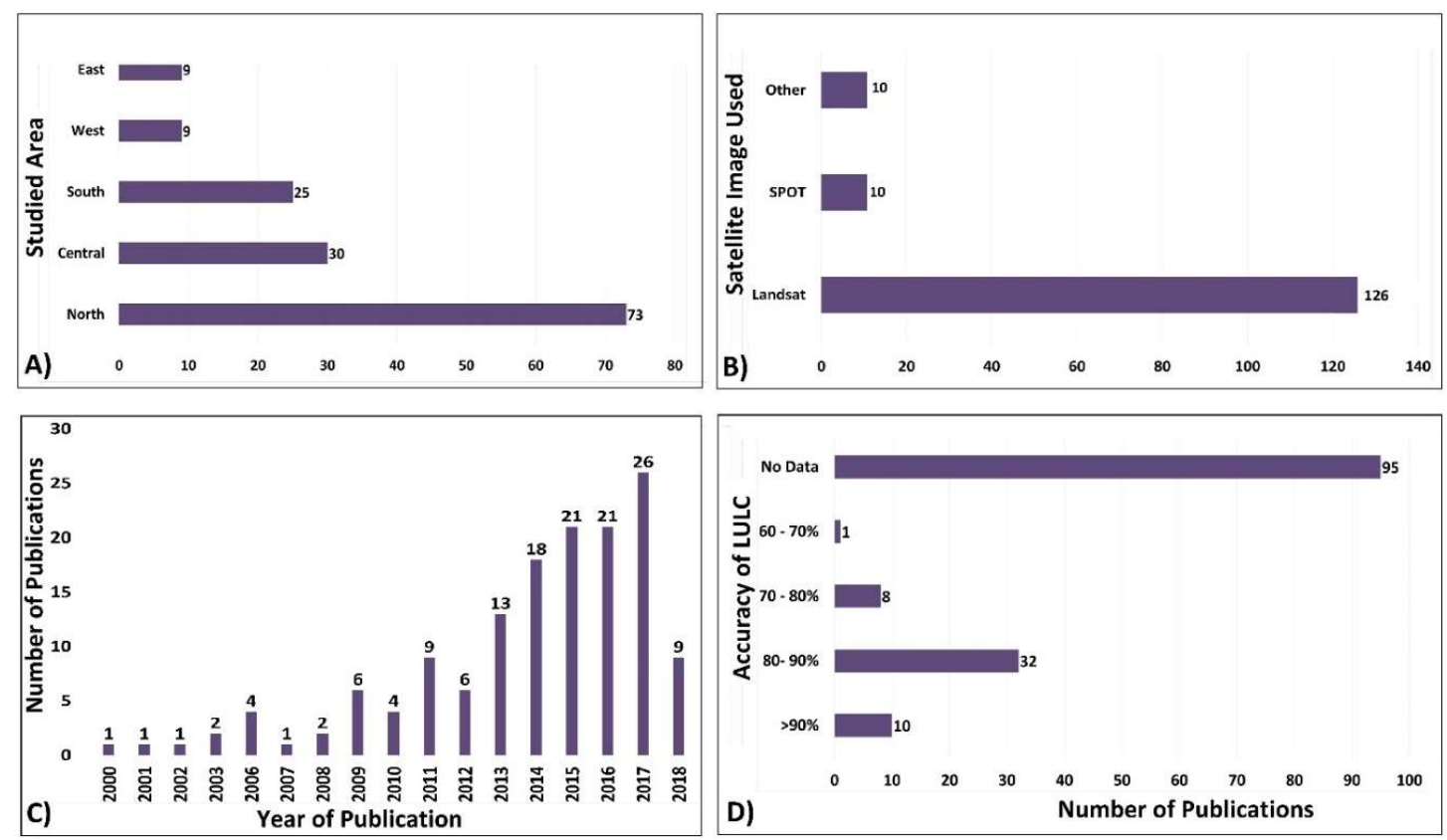

Figure 6. Number of publications in terms of their location (A), satellite image used (B), year of publication (C) and accuracy of LULC they produced (D).

\subsection{Evaluation of LULC products in the high-altitude area of the Bale Mountains National Park (national to global scale)}

Given most of the reviewed studies focus on mid- to high-altitude regions, we evaluated the accuracy of six of the available national to global scale LULC products in the BMNP area, which ranges between 1,500 and 4,385 m a.s.l (see Table 4, Fig. 6). Regarding the overall accuracy of these products, the S2GLC-2016 (49.19\%), ALCM-2015 (47.57\%), MODIS-2013 (41.77\%), GLC-SHARE-2014 (33.51\%), RCMRD/EMA-2013 (20.54\%), and GLCNMO-2013 (20.54\%) all have less than 50\% overall accuracy. The most accurate product for high-altitude areas - the 20m S2GLC-2016 - correctly explains the LULC classes there $49.19 \%$, which may indicate why they are infrequently utilized in the reviewed studies.

The producer accuracy (Table 4) reveals that tree cover (79.5\%) and cropland (55.6\%) is best explained by the MODIS product. Grassland (33.7\%), shrubland $(87.5 \%)$ and barren soil $(21.1 \%)$ is best predicted by RCMRD/EMA, S2GLC and ALCM, respectively. However, RCMRD/EMA shows $0 \%$ accuracy for grassland and barren soil. The same is true for GLC-SHARE but for cropland and barren soil. Tree Cover show highest value of user accuracy in all LULC products. That is, all land cover products are accurate in terms of classifying the Tree Cover class. 
Table 4. Producer and user accuracy of the LULC products.

\begin{tabular}{|c|c|c|c|c|c|c|c|}
\hline LULC Product & & $\begin{array}{c}\text { Tree } \\
\text { Cover }\end{array}$ & $\begin{array}{c}\text { Grassland } \\
\text { (Herbaceous) }\end{array}$ & Shrubland & Cropland & $\begin{array}{c}\text { Barren } \\
\text { land }\end{array}$ & $\begin{array}{c}\text { Overall } \\
\text { Accuracy }\end{array}$ \\
\hline \multirow[t]{2}{*}{ S2GLC } & PA & 73.8 & 32.5 & 77.8 & 22.2 & ${ }^{1} \mathrm{NaN}$ & \multirow{2}{*}{$49.19 \%$} \\
\hline & UA & 96.9 & 68.4 & 34.6 & 37.5 & 0.0 & \\
\hline \multirow[t]{2}{*}{ ALCM } & PA & 70.5 & $\mathrm{NaN}$ & 60.0 & $\mathrm{NaN}$ & 21.1 & \multirow{2}{*}{$47.57 \%$} \\
\hline & UA & 96.9 & 0.0 & 51.9 & 0.0 & 83.3 & \\
\hline \multirow[t]{2}{*}{ MODIS } & PA & 79.5 & 26.3 & 36.4 & 55.6 & $\mathrm{NaN}$ & \multirow{2}{*}{$41.77 \%$} \\
\hline & UA & 100.0 & 74.3 & 6.6 & 38.5 & 0.0 & \\
\hline \multirow[t]{2}{*}{ GLC-SHARE } & PA & 40.5 & 33.7 & $\mathrm{NaN}$ & 0.0 & 0.0 & \multirow{2}{*}{$33.51 \%$} \\
\hline & UA & 100.0 & 78.9 & 0.0 & 0.0 & 0.0 & \\
\hline \multirow[t]{2}{*}{ RCMRD/EMA } & PA & 29.7 & 0.0 & 87.5 & 1.4 & 0.0 & \multirow{2}{*}{$20.54 \%$} \\
\hline & UA & 93.8 & 0.0 & 8.6 & 6.2 & 0.0 & \\
\hline \multirow[t]{2}{*}{ GLCNMO } & PA & 34.0 & 6.2 & 15.4 & $\mathrm{NaN}$ & $\mathrm{NaN}$ & \multirow{2}{*}{$20.54 \%$} \\
\hline & UA & 100.0 & 5.3 & 4.9 & 0.0 & 0.0 & \\
\hline
\end{tabular}

${ }^{1}$ There is no LULC class in the product within BMNP. PA = Producer Accuracy and UA = User Accuracy 

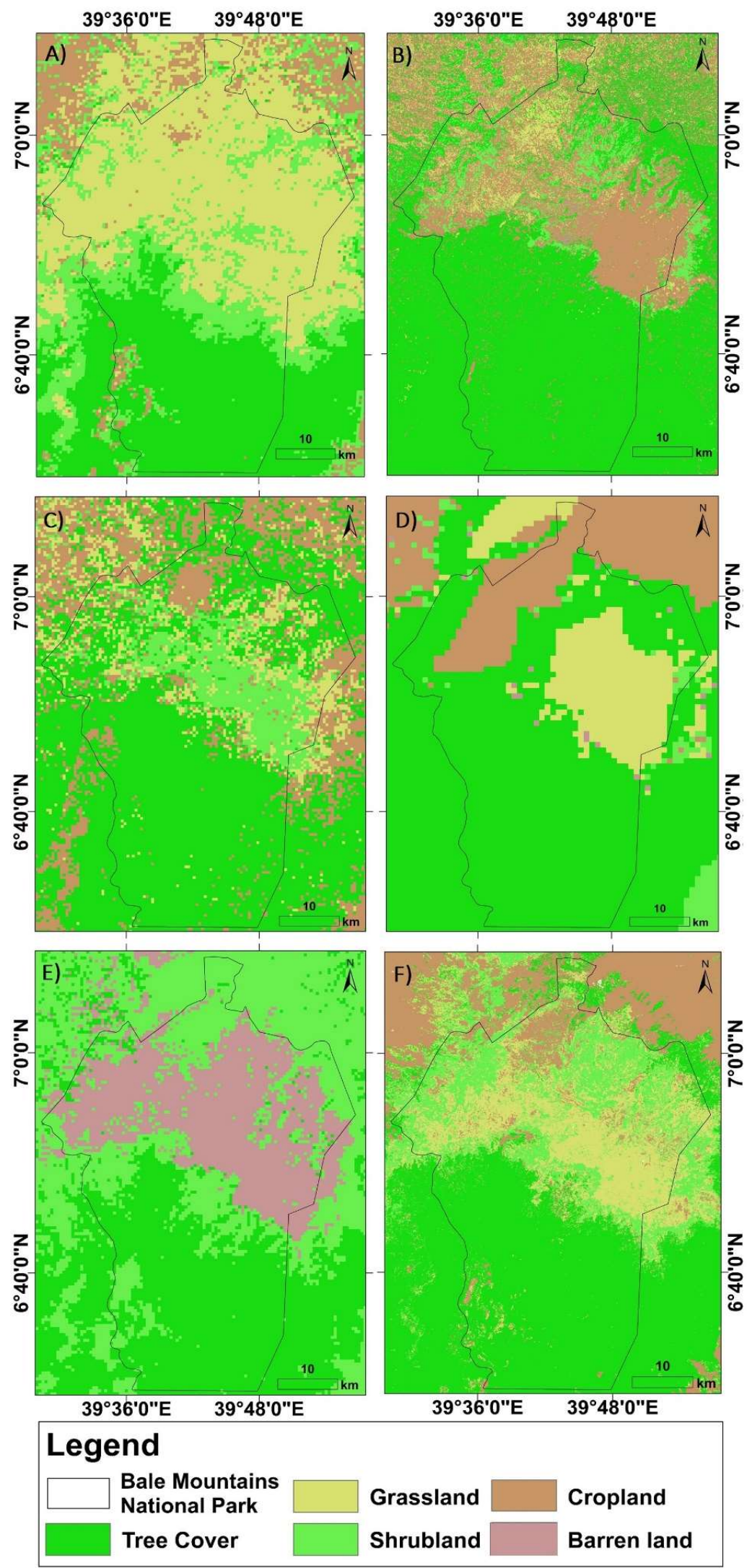

Figure 7. Maps of LULC products for BMNP: A) MODIS IGBP-2013 (500m); B) RCMRD and EMA2013 (30m); C) GLCNMO-2013 (500m); D) GLC-SHARE-2014 (1km); E) ALCM-2015 (500m); and F) S2GLC-2016 (20m). 
3 of 16

\section{Conclusions}

The review of 146 land use/land cover studies in Ethiopia revealed that in addition to the availability of national to global scale LULC products, most researchers (83\%) prefer to create a new LULC using satellite images like Landsat. About 73\% of the studies have been published since 2013 and no study since then has used an available LULC. This might be related to the rather poor overall accuracy $(<50 \%)$ of the available products, especially in high-elevation areas, where most studies have their focus.

Supplementary Materials: The LULC classification systems of identified products (Supplementary Document 1) and summary of all publications in spreadsheet format (Supplementary Document 2) are available alongside the manuscript.

Author Contributions: B.T. Hailu made substantial contributions in literature research, data analysis, interpretation of results, writing and leading the overall activities including the design and drafting the manuscript. M. Fekadu contributed with data collection, entry and coding. T. Nauss substantially contributed to the manuscript by revising important intellectual content and suggestions. Every author read and approved the final manuscript.

Funding: This work was supported by the German Research Council (DFG) through a project entitled "The Mountain Exile Hypothesis: How humans benefited from and re-shaped African high-altitude ecosystems during Quaternary climatic changes" within the framework of the Research Unit 2358-grant number NA 783/121, AOBJ 628803 (Marburg University, Germany; http:// bale.environmentalinformatics-marburg.de).

Acknowledgments: Dr. Binyam Tesfaw Hailu is currently a Georg Forster Post-doctoral Fellow with the Alexander Von Humboldt Foundation.

Conflicts of Interest: The authors declare no conflict of interest.

\section{References}

1. Midekisa, A.; Holl, F.; Savory, D.J.; Andrade-Pacheco, R., Gething, P.W., Bennett, A., et al. Mapping land cover change over continental Africa using Landsat and Google Earth Engine cloud computing. PLoS ONE, 2017, 12, 9, e0184926.

2. Hussein, A.O. Land use and land cover change, drivers and its impact: a comparative study from Kuhar Michael and Lenche Dima of Blue Nile and Awash basins of Ethiopia, PhD thesis, Faculty of the Graduate School, Cornell University, New York, USA, 2009.

3. Lambin, E.F.; Geist, H.J.; Lepers, E. Dynamics of land-use and landcover change in tropical regions. Ann. Review Environ Resources 2003, 28, 205-241.

4. Solomon, N.; Hishe, H.; Annang, T.; Pabi O.; Asante, I.K.; Birhane, E. Forest Cover Change, Key Drivers and Community Perception in Wujig Mahgo Waren Forest of Northern Ethiopia. Land, 2018, 7, 32.

5. Hailemariam, S. N.; Soromessa, T.; Teketay, D. Non-carbon benefits for effective implementation of REDD+: The case of Bale Mountains Eco-Region, Southeastern Ethiopia. Afr. J. Environ Sci Tech, 2015, 9, 747-764.

6. Othow, O.O.; Gebre, S.L.; Gemed, D.O. Analyzing the Rate of Land Use and Land Cover Change and Determining the Causes of Forest Cover Change in Gog District, Gambella Regional State, Ethiopia. J. Remote Sens. GIS 2017, 6, 4.

7. Kindu, M.; Schneider, T.; Teketay, D.; Knoke, T. Drivers of land use/land cover changes in MunessaShashemene landscape of the south-central highlands of Ethiopia. Environ Monit Assess. 2015, 187, 452.

8. MoFED. Growth and Transformation Plan 2010/11-2014/15, Federal Democratic Republic of Ethiopia Volume I: Main Text Draft, Addis Ababa, Ethiopia, 2010.

9. Boyd, D.S.; Danson, F.M. Satellite remote sensing of forest resources: three decades of research development. Prog. Phys. Geogr. 2005, 29, 1, 1-26.

10. Xie, Y.; Sha, Z.; Yu, M. Remote sensing imagery in vegetation mapping: a review. J Plant Ecol, 2008, 1, 923.

11. Wang, J.; Sammis, T.W.; Gutschick, V.P.; Gebremichael, M.; Dennis, S.O.; Harrison, R.E. Review of Satellite Remote Sensing Use in Forest Health Studies. The Open Geog. J., 2010, 3, 28-42. 
12. Dubovyk, O. The role of Remote Sensing in land degradation assessments: opportunities and challenges. Eur J Remote Sens, 2017, 50, 1, 601-613.

13. FAO (Food and Agriculture Organization) of the United Nations. Review of the available Remote sensing tools, products, methodologies and data to improve crop production forecasts. Rome, Italy, 2017.

14. Xiao, Y.; Zhan, Q. A Review of Remote Sensing Applications in Urban Planning and Management in China. IEEE 2009 Urban Remote Sens Joint Event, Shanghai, China 2009.

15. Yang, J.; Gong, P.; Fu, R.; Zhang, M.; Chen, J.; Liang, S.; Xu, B.; Shi, J.; Dickinson, R. The role of satellite remote sensing in climate change studies. Nat. Clim. Change, 2013, 3, 875-883.

16. Wang, W.; Yang, N.; Zhang, Y.; Fengping, W.; Cao, T., Eklund P. A review of road extraction from remote sensing images. J. Traffic Transp. Eng. (Engl. Ed.), 2016, 3, 271-282.

17. Tomlinson, C.J.; Chapman, L.; Thornes, J.E.; Baker, C. Remote sensing land surface temperature for meteorology and climatology: a review. Meteorol Appl, 2011, 18, 296-306.

18. Cook, D.J.; Mulrow, C.D.; Haynes, R.B. Systematic reviews: synthesis of best evidence for clinical decisions. Ann Intern Med. 1997, 126, 376-380.

19. Friedl, M. A.; Sulla-Menashe, D.; Tan, B.; Schneider, A.; Ramankutty, N.; Sibley, A.; Huang, X. MODIS Collection 5 global land cover: Algorithm refinements and characterization of new datasets. Remote Sens Environ. 2010, 114, 168-182.

20. Bartholomé, E.; Belward, A.S. GLC2000: A new approach to global land cover mapping from Earth observation data. Int. J. Remote Sens. 2005, 26, 1959-1977.

21. Pflugmacher, D.; Krankina, O.N.; Cohen, W.B.; Friedl, M.A.; Sulla-Menashe, D.; Kennedy, R.E.; Nelson, P.; Loboda, T.V.; Kuemmerle, T.; Dyukarev, E.; et al. Comparison and assessment of coarse resolution land cover maps for northern Eurasia. Remote Sens. Environ. 2011, 115, 3539-3553.

22. Fritz, S.; Bartholomé, E.; Belward, A.; Hartley, A.; Stibig, H.J; Eva, H. Harmonization, mosaicking, and production of the Global Land Cover 2000 database, Joint Research Center, Ispra, Italy, 2003.

23. Bartalev, S.A.; Belward, A.S.; Erchov, D.V.; Isaev, A.S. A new Spot4-vegetation derived land cover map of northern Eurasia. Int. J. Remote Sens. 2003, 24, 1977-1982.

24. Bicheron, P.; Defourny, P.; Brockmann, C.; Schouten, L.; Vancutsem, C.; Huc, M.; Bontemps S.; Leroy, M.; Achard, F.; Herold M.; et al. GLOBCOVER Products Description and Validation Report; Toulouse Cedex 9, France, 2008.

25. Bontemps, S.; Defourny, P.; Van Bogaert, E.; Arino, O.; Kalogirou, V.; Ramos-Perez, J. GlobCover 2009_ Products Description and Validation Report; European Space Agency (ESA): Paris, France, 2011.

26. Arino, O.; Perez Ramos, J.; Kalogirou, V.; Bontemps, S.; Defourny, P.; Van Bogaert, E. Global Land Cover Map for 2009 (GlobCover 2009); European Space Agency (ESA) \& Université Catholique de Louvain (UCL): Frascati, Italy, 2012.

27. RCMRD-SERVIR Africa. Land cover mapping for greenhouse gas inventories development Project in east and southern Africa region. Ethiopian Mapping Agency, Addis Ababa, Ethiopia, 2015.

28. Chen, J.; Chen, J.; Liao, A.P.; Cao, X.; Chen, L., Chen, X..; He, C.; Han, G.; Peng, S.; Lu, M.; et al. Global land cover mapping at $30 \mathrm{~m}$ resolution: A POK-based operational approach. ISPRS J. Photogramm., 2015, 103, $7-27$.

29. Chen, J.; Ban, Y.; Li, S. China: Open access to Earth land-cover map. Nature, 2014, 514, 434-434.

30. Tateishi, R.; Bayaer, U.; Al-Bilbisi, H.; Aboel Ghar, M.; Tsend-Ayush, J.; Kobayashi, T.; Kasimuf, A.; Thanh Hoan, N.; Shalaby, A.; Alsaaideh, B.; et al.). Production of global land cover data - GLCNMO, Int J Digit Earth., 2011, 4, 22-49.

31. Tateishi, R.; Thanh Hoan, N.; Kobayashi, T.; Alsaaideh, B.; Tana, G.; Xuan Phong, D. Production of Global Land Cover Data - GLCNMO2008. J. Geog. Geol., 2014, 6, 99-122.

32. Latham, J.; Cumani, R.; Rosati, I.; Bloise, M. Global Land Cover SHARE (GLC-SHARE) database BetaRelease Version 1.0. Rome, Italy, 2014.

33. Masek, J.G.; Vermote, E.F.; Saleous, N.E.; Wolfe, R.; Hall, F.G.; Huemmrich, K.F.; et al. A Landsat surface

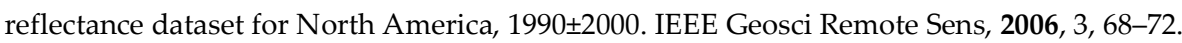

34. U.S. National Oceanographic and Atmospheric Administration, http://ngdc.noaa.gov/eog/

35. Lewiński, S.; Nowakowski, A.; Malinowski, R.; Rybicki, M.; Kukawska, E.; Krupiński, M. Aggregation of Sentinel-2 time series classifications as a solution for multitemporal analysis. Image and Signal Processing for Remote Sensing XXIII, 104270B. 2017. 
36. Lewiński, S.; Nowakowski, S.; Rybicki, M.; Kukawska, E.; Malinowski, R.; Krupiński, M.; Krätzschmar, E.; Hofmann, P.; Bielski, C.; Dejon, D.; et al. Towards Automatic Global Land Cover Classification on Sentinel2 Data, World Cover 2017 Conference, 14-16 March 2017, ESA-Esrin, Frascati, Italy, 2017.

37. Asmamaw, L.B., Mohammed, A.A., Lulseged T.D. Land use/cover dynamics and their effects in the Gerado catchment, northeastern Ethiopia. Int. J. Environ. Studies, 2012, 68:6, 883-900.

38. Woldesenbet, T.A.; Elagib, N.A.; Ribbe, L.; Heinrich, J. Hydrological responses to land use/cover changes in the source region of the Upper Blue Nile Basin, Ethiopia. Sci Total Environ. 2017, 575, 724-741.

39. Yeshaneh, E.; Wagner, W.; Exner-Kittridge, M.; Legesse, D.; Blöschl, G. Identifying Land Use/Cover Dynamics in the Koga Catchment, Ethiopia, from Multi-Scale Data, and Implications for Environmental Change. ISPRS int. j. geo-inf., 2013, 2, 302-323.

40. Asmamaw, L. B.; Mohammed, A. A. Effects of slope gradient and changes in land use/cover on selected soil physico-biochemical properties of the Gerado catchment, north-eastern Ethiopia, Int. J. Environ. Studies, 2012, 70, 111-125.

41. Reid, R.S.; Kruska, R.L.; Muthui, N.; Taye, A.; Wotton, S.; Wilson, C.J.; Mulatu, W. Land-use and land-cover dynamics in response to changes in climatic, biological and socio-political forces: the case of southwestern Ethiopia. Landscape Ecol., 2000, 15, 339.

42. Gashaw, T.; Tulu, T.; Argawa, M.; Worqlul, A.W. Modeling the hydrological impacts of land use/land cover changes in the Andassa watershed, Blue Nile Basin, Ethiopia. Sci Total Environ. 2018, 619-620, 1394-1408.

43. Biazin, B.; Sterk, G. Drought vulnerability drives land-use and land cover changes in the Rift Valley dry lands of Ethiopia. Agric. Ecosyst. Environ. 2013, 164, 100-113.

44. Teferi, E.; Bewket, W.; Uhlenbrook S.; Wenninger J. Understanding recent land use and land cover dynamics in the source region of the Upper Blue Nile, Ethiopia: Spatially explicit statistical modeling of systematic transitions. Agric. Ecosyst. Environ. 2013, 165, 98-117.

45. Kidane, Y.; Stahlmann, R.; Beierkuhnlein, C. Vegetation dynamics, and land use and land cover change in the Bale Mountains, Ethiopia. Environ Monit Assess. 2012, 184, 7473-7489.

46. Teferi, E.; Bewket, W.; Simane, B. Effects of land use and land cover on selected soil quality indicators in the headwater area of the Blue Nile basin of Ethiopia. Environ Monit Assess, 2016, 188, 83.

47. Haregeweyn, N.; Tesfaye, S.; Tsunekawa, A.; Tsubo, M.; Meshesha, D.T.; Adgo, E.; Elias, A. Dynamics of land use and land cover and its effects on hydrologic responses: case study of the Gilgel Tekeze catchment in the highlands of Northern Ethiopia. Environ Monit Assess. 2015, 187, 4090.

48. Wubie, M. A., Assen, M., Nicolau, D. Patterns, causes and consequences of land use/cover dynamics in the Gumara watershed of lake Tana basin, Northwestern Ethiopia. Environ Syst Res., 2016, 5, 8.

49. Hassen, E. E.; Assen, M. Land use/cover dynamics and its drivers in Gelda catchment, Lake Tana watershed, Ethiopia. Environ Syst Res. 2017, 6, 4.

50. Warra, H.H.; Mohammed, A.; Nicolau, M.D. Spatio-temporal impact of socio-economic practices on land use/ land cover in the Kasso catchment, Bale mountains, Ethiopia. Scientific annals of "Alexandru Ioan Cuza" University of IAŞI, 2013, 59, 1.

51. Miheretu, B.A.; Yimer, A.A. Land use/land cover changes and their environmental implications in the Gelana sub-watershed of Northern highlands of Ethiopia. Environ Syst Res, 2017, 6, 7.

52. Bewket, W.; Abebe, S. Land-use and land-cover change and its environmental implications in a tropical highland watershed, Ethiopia. Int. J. Environ. Studies, 2013, 70, 126-139.

53. Worku, G.; Bantider, A.; Temesgen, H. Effects of Land Use/Land Cover Change on Some Soil Physical and Chemical Properties in Ameleke micro Watershed, Gedeo and Borena Zones, South Ethiopia. J. Environ Earth Sci, 2014, 4, 11.

54. Tilahun, A.K. Land Use Land Cover Change and Its Implication on Surface Runoff: A Case Study of Baro River Basin in South Western Ethiopia. J. Environ Earth, 2015, 5, 8.

55. Gashaw, T.; Fentahun, T. Evaluation of Land Use/ Land Cover Changes in East of Lake Tana, Ethiopia. Environ. Earth Sci. 2014, 4, 11.

56. Biru M. K.; Minale A.S.; Debay A.B. Multitemporal Land Use Land Cover Change and Dynamics of Blue Nile Basin by Using GIS and Remote Sensing Techniques, North-Western Ethiopia. Int. J. Environ. Sci. 2015, $4,2,81-88$.

57. Tadesse, L.; Suryabhagavan, K.V.; Sridhar, G.; Legesse, G. Land use and land cover changes and Soil erosion in Yezat Watershed, North Western Ethiopia. Int. Soil Water Cons. Res. 2017, 5, 2, 85-94 
58. Jemberie, M.; Gebrie, T.; Gebremariam, B. Evaluation of land use land cover change on stream flow: a case study of Dedissa sub basin, Abay basin, south western Ethiopia. Int. j. innov. eng. 2016, 3, 44-60.

59. Fisseha, G.; Gebrekidan, H.; Kibret, K.; Yitaferu, B.; Bedadi, B. Analysis of land use/land cover changes in the Debre-Mewi watershed at the upper catchment of the Blue Nile Basin, Northwest Ethiopia. J. Biodiv. Environ. Sci. 2011, 1, 6, 184-198.

60. Hassaballah, K.; Mohamed, Y.; Uhlenbrook, S.; Biro, K. Analysis of streamflow response to land use and land cover changes using satellite data and hydrological modelling: case study of Dinder and Rahad tributaries of the Blue Nile (Ethiopia-Sudan). Hydrol. Earth Syst. Sci. 2017, 21, 5217-5242.

61. Andualem, T.G.; Gebremariam, B. Impact of Land Use Land Cover Change on Stream Flow and Sediment Yield: A Case Study of Gilgel Abay Watershed, Lake Tana Sub-Basin, Ethiopia. Int. J. Technol. Enhanc. Merg. Eng. Res., 2015, 3, 28-42.

62. Minale, A.S. Retrospective Analysis of Land Cover and Use Dynamics in Gilgel Abbay Watershed by Using GIS and Remote Sensing Techniques, Northwestern Ethiopia. Int. J. Geosci., 2013, 4, 1003-1008.

63. Tsegaye, D.; Moe, S.R.; Vedeld, P.; Aynekulu, E. Land-use/cover dynamics in Northern Afar rangelands, Ethiopia. Agric. Ecosyst. Environ, 2010, 139, 174-180.

64. Minale, A.S.; Rao, K.K. Impacts of land cover/use dynamics of Gilgel Abbay catchment of Lake Tana on climate variability, Northwestern Ethiopia. Appl Geomat., 2012, 4, 155-162.

65. Tufa, D.F.; Abbulu, Y.; Srinivasa Rao, G.V.R. Hydrological Impacts due to Land-Use and Land-Cover Changes of Ketar Watershed, Lake Ziway Catchment, Ethiopia. Int. J. Civ. Eng Tech. 2015, 6, 36-45.

66. Gessesse, B.; Bewket; W., Bräuning, A. Model-Based Characterization and Monitoring of Runoff and Soil Erosion in Response to Land Use/Land Cover Changes in The Modjo Watershed, Ethiopia. Land Degrad. Develop. 2015, 26, 711-724.

67. Mengesha, G.; Bekele, A.; Fraser, G.; Mamo, Y. Land use, land cover and climate change impacts on the bird community in and around Lake Zeway, Ethiopia. Int. J. Biodivers. Conserv., 2014, 6, 3, 256-270. 